ISSN 2078-6077.

Наукові зошити історичного факультету Львівського університету. 2018-2019. Випуск 19-20. С. 449-464

Proceedings of History Faculty of Lviv University. 2018-2019. Issue 19-20. P. 449-464

УДК 94(477.83-25):304-054.6”1939.09”(093.3)

\title{
ДЕВ’ЯТЬ ДНІВ “ЗОЛОТОГО ВЕРЕСНЯ” 1939 роКУ У СПОГАДАХ УКРАЇНСЬКИХ ЕМІРАНТІВ ЗІ ЛЬВОВА
}

\author{
Зоя БАРАН \\ Львівський національний університет імені Івана Франка \\ кафедра нової та новітньої історії зарубіжних країн \\ вул. Університетська, 1, Львів, 79000, Україна \\ e-mail: zoja_baran@ukr.net
}

\begin{abstract}
У статті на основі опублікованих у повоєнний час, головно в США, спогадів українських львів'ян-емігрантів відтворено перші дев'ять днів радянської окупації Львова 1939 р. Автори мемуарів - люди різного роду занять та віку: письменники, правники, лікарі. Їхні спогади та опубліковані матеріяли, зібрані безпосередньо під час та після згаданих подій, дозволили відтворити перші враження міщан про вояків Червоної армії, радянських чиновників (чоловіків та жінок), які прибули до міста. Можна виокремити дві прикмети радянських людей, які кидалися у вічі всім без винятку авторам: бідність, що свідчило про справжню економічну ситуацію в УРСР та СРСР, та відсутність елементарних норм культури поведінки, що віддзеркалювало соціяльно-побутовий уклад життя радянської людини загалом. Щодо суспільних настроїв, то, 3 одного боку, українська людність міста перебувала в ейфорії від звільнення 3-під польського панування, з іншого, зважаючи на зовнішні ознаки прибулих, манеру поведінки та дії новопосталої влади, сприйняло ії з недовірою, а подекуди, й з острахом. І небезпідставно, оскільки закриття часописів, перші арешти громадських та політичних діячів поклали край сподіванням на українізацію та демократизацію життя в місті. Львів змінювався не лише політично, але й під впливом радянізації швидко відбувалася трансформація публічного простору, культурних моделей.

Ключові слова: Львів, “золотий вересень 1939”, радянська окупація, Червона армія.
\end{abstract}

Унаслідок радянсько-німецьких домовленостей 1939 р. Західна Україна опинилася у сфері інтересів СРСР. Отож, війська Червоної армії перейшли кордон 17 вересня 1939 р. і незабаром увійшли до Львова. Історична пам'ять про той час відображена в численній мемуарній літературі. Спогади передають атмосферу епохи, віддзеркалюють суспільні погляди, що панували в тогочасному Львові. Звісно, мемуаристика є джерелом суб'єктивним, а тому потребує критичного аналізу із залученням інших матеряалів.

Однією з перших, “по гарячих слідах", збирала спогади та згодом їх опублікувала відома представниця галицького жіночого руху міжвоєнного часу Мілена Рудницька. Йдеться про збірник “Західня Україна під большевиками” 3 матеріялами про першу радянську окупацію вересня 1939 - червня 1941 років ${ }^{1}$. Це переважно записи громадян Львова різного статусу та занять без зазначення

\footnotetext{
1 Західя Україна під большевиками. Упоряд. Мілена Рудницька. (Нью-Йорк: Наукове товариство ім. Шевченка в США, 1958). 494 с. (перевидання книжки здійснено 2016; упорядники Степан та Галина Поповичі).
} 
ISSN 2078-6077. Наукові зошити історичного факультету Львівського університету. 2018-2019. Випуск 19-20. Proceedings of History Faculty of Lviv University. 2018-2019. Issue 19-20.

авторства. Однак серед них важливо виокремити спогади голови товариства “Просвіти” Івана Брика (1879-1947); старійшини галицького політикуму Костя Левицького (1859-1941); теолога, письменника Гавриїла Костельника (18861948). Цікавими є також спогади на той час львів'янина, активного громадського діяча, згодом відомого фольклориста Івано-Франківщини Івана Прокопова ${ }^{2}$ (06. 03. 1901, с. Слобода Рунгурська Івано-Франківської обл. - 1973). Зацікавили нас ці сюжети з огляду на можливість їх порівняння зі спогадами інших львів' ян, котрі з політичних причин емігрували за кордон упродовж 40-х років і там опублікували свої мемуари. Власне вони й стали джерелом для написання цієї студії. Серед авторів: Осип Назарук (31. 08. 1883, м. Бучач Тернопільської обл. 31. 03. 1940, Краків, Польща) - громадський і політичний діяч, письменник, публіцист ${ }^{4}$; Адольф Слиж (25. 08. 1889, с. Слобідка Лісна Івано-Франківської обл. - 06. 04. 1971, Нью-Йорк, США) - український правник ${ }^{5}$; Іван Німчук (12. 02. 1891, с. Джурин Тернопільської обл. - 01. 05. 1956, Едмонтон, Канада) журналіст, редактор низки українських видань ${ }^{6}$; Наталя Яхненко (літературний псевдонім Наталії Зибенко-Пирогової - дочка лікаря Миколи Пирогова; 03. 09. 1903, Ковель Волинської обл. - 1995, Сідней, Австралія) - письменниця, у перші дні радянської окупації працювала в кооперативному товаристві Сільський Господар) 7 , Михайло Логаза (09. 10. 1906, с. Підпечари Івано-Франківської області - 11. 01. 1989, м. Сиракузи, США) - лікар, меценат, член НТШ Мирослав Семчишин (26. 08. 1910, с. Почапи Львівської обл. - 05. 02. 1999, м. Чикаго, США) - випускник філософського факультету Львівського університету, у міжвоєнний період вчитель української мови львівської академічної гімназії, в 1939-1941 р. викладав у Львівському університеті, автор численних праць, зокрема монографії “Тисяча років української культури” 9; Остап Тарнавський (псевдоніми Тарас Кульчицький, Лесь Юрчик, 03. 05. 1917, Львів 19. 09. 1992, Філадельфія, США) - поет, перекладач, письменник, літературний критик ${ }^{10}$; Мирослав Харкевич $(1917$, с. Іллінці Івано-Франківської обл. -

${ }^{2}$ Архип Данилюк, Шляхами Украйни. Етнографічний нарис. (Львів: Видавництво “Світ”, 2003), $232 \mathrm{c}$

${ }^{3}$ Іван Васильович Прокопів, Спогади. Львівська національна наукова бібліотека України імені В. Стефаника. Відділ рукописів, ф. Прок. 75, п. 7. 193 с.

${ }^{4}$ Осип Назарук, Зі Львова до Варшави. Утеча перед совітами в памятних днях 2-13 жовтня 1939 року. (Львів: Наукове товариство ім. Шевченка, 1995). 96 с.

${ }^{5}$ Адольф Слиж, Літа. Спогади. (Львів: Манускрипт, 2014). 156 с.

6 Іван Німчук, 595 днів совєтським вязнем, (Торонто, 1950). 238 с.

${ }^{7}$ Наталя Яхненко, Від Бюра до Бритідок. Трохи спогадів з 1939-1941 років. (Львів; БераляМюнхен, 1986). 263 с.

${ }^{8}$ Михайло Логаза, Таке то в нас життя. Спогади-промови-есеї-коментарі. Вибране про охорону здоров'я. (Сиракюзи; Нью Йорк: Накладом автора, 1985). 353 с.

${ }^{9}$ Спогади, написані в Чикаго 1997 р.: Мирослав Семчишин, 3 книги Лева. Украӥнський Львів двадиятих-сорокових років. Спомини. (Львів: Наукове товариство ім. Шевченка, 1998). 146 с.

${ }^{10}$ Остап Тарнавський, Літературний Львів, 1939-1944: спомини. (Львів: Піраміда, 1995). $136 \mathrm{c}$. 
02. 10. 2001, Чикаго, США ${ }^{11}$ ) - лікар, член ОУН ${ }^{12}$; Степан Мудрик (псевдо "Мечник", 05. 10. 1919, с. Криве Львівської обл. - 20. 04. 2004, Новий Ульм, Німеччина) - член ОУН ${ }^{13}$; Михайло Яворський (10. 04. 1921, с. Явора Львівської обл. - 30. 03. 2016, Нью-Йорк, США ${ }^{14}$ ) - письменник, член ОУН, професор політології Міського Університету Нью-Йорка ${ }^{15}$; Степан Петелицький (24. 05. 1923, с. Ушня Львівської обл. - 2018, Ванкувер, Канада) - в'язень нацистських таборів Освенціму та Ебензе ${ }^{16}$.

Авторам одинадцяти мемуарів, які переважно видані у США, було станом на 1939 рік від 14 до 56 років. Свої спогади вони писали вже у зрілому віці. Проаналізовані джерела дали можливість виокремити такі аспекти у висвітленні перших дев'яти днів радянської окупації Львова - “золотого вересня” 1939 року як образ воїна Червоної армії та перших радянських чиновників, їх дружин, формування нової військової та цивільної адміністрації, побут, реакція української громади міста.

Уже $з$ початком Другої світової війни до Львова масово почали прибувати втікачі з західних регіонів Польщі, серед яких чи не найбільше було євреїв, які рятувалися від ймовірних погромів унаслідок німецької окупації Польщі ${ }^{17}$. У п'ятницю 22 вересня 1939 р. Червона армія зайняла Львів. Командування польського війська в місті оголосило про свою капітуляцію ${ }^{18}$ та за домовленістю 3 радянськими військовими очільниками польська залога - 15 тис. солдат та 1500 офіцерів - склала зброю, а гарантію недоторканности та право покинути

11 Мирослав Харкевич, http://www.legacy.com/memorial-sites/veterans/profilesearch.aspx? \&firstname=Myroslaw\% 20\&lastname=\%20Charkewycz\%20\&daterange=9999, доступ отримано 9 червня 2018.

12 Мирослав Харкевич, Я вас не забув. Спогади 1935-1935. (Нью-Йорк, Чікаго: Накладом українсько-американської фундації “Воля”, 1997). 288 с.

${ }^{13}$ Степан Мечник, Під трьома окупантами: спогади украӥнського револючуінера-підпільника. Памяті полеглих Героїв за волю України. (Лондон: Накладом Української видавничої спілки, 1958). $106 \mathrm{c}$.

${ }^{14}$ Некролог, Michael Jaworskyj, http:/www.pagosasun.com/michael-jaworskyj/, доступ отримано 9 червня 2018.

${ }^{15}$ Михайло Яворський автор двох романів “Поцілунок Лева” (2006), “Володар” (2008). Попри художню форму твору, автор стверджує, що “Поцілунок Лева” писав зі своїх спогадів. Михайло Яворський, Поцілунок Лева. Роман. (Львів: літературна агенція Піраміда, 2006).

${ }^{16}$ Степан Петелицький, До Освенціму за Украӥну. Пер. $з$ анг. О. Тереха. (Київ: Суспільна Служба України, 2000). 120 с.

${ }^{17}$ Мирослав Семчишин, 3 книги Лева, 62; Włodzimierz Bonusiak, “Mieszkańcy Lwowa podczas II wojny światowej”, Львів: місто - суспільство - культура: Збірник наукових праць. За ред. Олени Аркуші й Мар'яна Мудрого. Т.6: Львів; Краків: діалог міст в історичній ретроспективі. (Вісник Львівського університету. Серія історична. Спеціальний випуск . (Львів: Львівський національний університет імені Івана Франка, 2007), 536.

18 Машинописні копії матеріялів з газет з повідомленням про звільнення Львова і Українські Народні Збори, Державний архів Львівської області (далі - ДАЛО), ф. Р-300, оп. 1, спр. 44. арк. 15; Mykola Łytwyn, "Wojskowa kampania niemiecko-sowiecka roku 1939 w Galicji” w Od wojny do wolności. Wybuch i konsekwencje II wojny światowej 1939-1989, redakcja naukowa Marek Andrzejewski, Grzegorz Berendt, Tomasz Chinciński, Andrzej Trzeciak. (Gdańsk; Warszawa: Wydawnictwo Naukowe Scholar Spólka, 2010), 56. 
ISSN 2078-6077. Наукові зошити історичного факультету Львівського університету. 2018-2019. Випуск 19-20. Proceedings of History Faculty of Lviv University. 2018-2019. Issue 19-20.

Україну отримали всі офіцери та генерали. Однак умови протоколу були порушені радянською стороною: частини Червоної армії та НКВС при виході з міста оточили колони поляків та заарештували їх. Про успіх акції було негайно повідомлено до Москви ${ }^{19}$. Відразу зазначимо, що в жодних спогадах не згадуються розстріли польських воїнів та поліцейських, здійснені радянськими солдатами у перші дні, хоча це встановлений факт ${ }^{20}$. Водночас, щоб розвантажити потік військовополонених та посилити моральний розклад польських військових частин 23 вересня нарком оборони СРСР Климент Ворошилов надіслав наказ командуванню Українського фронту звільняти військовополонених селян-українців, мобілізованих на території Західної України. На основі того наказу командувач Українського фронту Семен Тимошенко видав розпорядження негайно відпустити по домівках полонених солдат - українців і білорусів, батьки яких мешкають на теренах Західної України та Західної Білорусі ${ }^{21}$. Про марш “безладної юрби вояків у польських уніформах, але без зброї" "від сторони Львова" з характерним білоруським акцентом згадувала у своїх спогадах Наталя Яхненко 22 .

Напередодні та під час вступу Червоної армії до Львова, літаки розкидали над містом листівки українською мовою. У них йшлося про визволення українського народу з польської неволі, передання землі селянам та фабрик робітникам, обіцянки розвитку української культури та науки. Були також запевнення про те, що радянська влада не цікавиться минулим громадян, а вимагає тільки лояльности до себе. Що цікаво, частина листівок містила промови послів УНДО в польському Соймі, зокрема Дмитра Великановича ${ }^{23}$, який подав статистику полонізації українського шкільництва. Однак згодом Д. Великановича, як і майже всіх послів і сенаторів, інших діячів українського руху радянська влада заарештувала і вивезла 3 краю ${ }^{24}$.

\footnotetext{
${ }^{19}$ Кім Науменко, “Місто напередодні і на початку світової війни” в книзі Історія Львова. У трьох томах. Том 3. Листопад 1918 - поч. ХХІ cm. Редколегія Ярослав Ісаєвич, Микола Литвин, Феодосій Стеблій. (Львів: Центр Європи, 2007), 168-169.

${ }^{20}$ Микола Литвин, Олександр Луцький, Кім Науменко, 1939. Західноукраӥнські землі Украӥни. (Львів: Інститут українознавства ім. Крип’якевича НАН України, 1999), 85.

${ }^{21}$ Там само, 73.

${ }^{22}$ Наталя Яхненко, Від Бюра до Бритідок, 11.

${ }^{23}$ Дмитро Великанович як посол до польського Сойму (1928-1939) відстоював інтереси українського шкільництва. (Див.: Дмитро Великанович, “Українське вчительство в Польщі у світлі статистики", Рідна школа (Львів), 1936, ч .19, 193-195; Дмитро Великанович, "Шкільна політика супроти України (з промови посла Великановича, виголошена на пленарному засіданні сойму 21 лютого 1936 р. при бюджеті міністерства освіти) "Рідна школа" (Львів), 1936, ч. 7-8, 108-109; Дмитро Великанович, "Українське вчительство в Польщі у світлі статистики”, Свобода. Український щзоденник (Джерзі Ситі), 22. 10. 1938, рік XLVI, ч. 246, 2-3.

${ }^{24}$ Іван Німчук, 595 днів совєтським вязнем, 19-20. Дмитра Великановича після арешту органами НКВС вислали в Оренбурзьку область і засудили 1945 р. до розстрілу. В 1998 р. реабілітований (Див.: Степан Гелей, Дмитро Великанович. Наукове товариство імені Шевченка. Енциклопедія. Т. 2. Бібл-Вес. Ред. тому: О. Купчинський (відп. ред.), О. Савула, Н. Федорак. Наукове товариство ім. Шевченка; Інститут енциклопедичних досліджень НАН України. Київ, Львів, Тернопіль, 2014, 544.
} 
ISSN 2078-6077. Наукові зошити історичного факультету Львівського університету. 2018-2019. Випуск 19-20. Proceedings of History Faculty of Lviv University. 2018-2019. Issue 19-20.

Перше враження від радянських військ, як свідчать спогади, однакові: розчарування від побаченого зовнішнього вигляду вояків та техніки, що іiі супроводжувала ${ }^{25}$. Степан Петелицький у своїх спогадах писав, що “був дуже здивований тим, наскільки бідний і обшарпаний вони мали вигляд. Війська були погано обмундировані і оснащені, на відміну від пишної аристократичної армії, під якою ми жили в часи польської окупації. Нам здавалось дивним і вселяло сумніви, коли, незважаючи на їх очевидну нужденність, совєтські представники наполегливо всім розповідали, як у СССР всі громадяни мають повну зайнятість, медичне обслуговування, освіту, продукти харчування, житло і оплачувані відпустки" 26. Подібні враження в Івана Німчука: “побачили совєтські танки. Залога тих танків... була якась вистрашена і виглядала така перемучена, якби мала за собою бодай кілька місяців боїв і тисячі кільометрів пройденої дороги. Тим часом червона армія вїздила до Львова без одного вистрілу, бо хто ж мав ставити їй опір”27. I далі: “червона армія була дивно виснажена і виголоджена, до того ж вся вона мала на собі такі нужденні уніформи, що вони просто відбивали своєю вбогістю та знищенням від добірної якости уніформ, що їх носили вояки німецькі чи польські”28. “Заболочені черевики, за плечима рушниці, на грудях пояс із патронами, над касками вістря багнетів - здавалось, вони щойно зійшли 3 екранів фільмів про Першу світову війну"29. Осип Назарук описує свої враження так: “За якийсь час почав над'їдити цілий ряд совітських танків 3 великим звенькотом і тарахкотінням. Ті танки були великі і малі, ріжного вигляду, але всі помальовані однакою краскою, якоюсь бурою. Деякі були щільно замкнені, на деяких видно було червоноармійців. Вони держали кріси в руках і дивилися у вікна, мабуть побоюючись, що будуть в них стріляти. Одяги їх були гірші від одягів польських жовнірів, а 3 німецькими їх порівнювати годі було. Вигляд совітських жовнірів був переважно марний і зовсім не пригадував добре виглядаючих рослих солдатів бувшої царської армії. Червоноармійці займали Львів мовчки: не чути було не то співу, але навіть не видно було, щоб вони говорили між собою або засміялись" ${ }^{\text {" }}$. Наталя Яхненко також підкреслила, що “зовнішній

${ }^{25}$ Степан Мечник, Під трьома окупантами: спогади украӥнського революиіонера-підпільника, 23. Іван Прокопів у спогадах занотував: “Нас дивувала бідність їх одягу, озброєння. Їх дивувало, що ми всі добре виглядаємо і добре одягнені, не лише інтелігенція, але й робітники. А їм говорили, що ми не маємо в що одягнутися, що ми обдерті” (Іван Васильович Прокопів, Спогади, 34).

${ }^{26}$ Петелицький, Степан. До Освенціму за Украӥну, 22.

${ }^{27}$ Іван Німчук, 595 днів совєтським вязнем, 18.

${ }^{28}$ Там само, 19.

${ }^{29}$ Михайло Яворський, Поцілунок Лева. Роман. Львів: літературна агенція Піраміда, 2006, 42. Степан Мудрик згадував, що його односельці сприйняли такий образ червоноармійців наслідком тривалих переходів та битв, але старші люди, які “бачили москалів ще в першій світовій війні, твердили, що це взагалі нормальний для російського солдата вигляд”. Щоправда, визнавали селяни, в ті часи солдати все таки виглядали краще. Нинішніх воїнів "Сталін годує либонь газетою" (Степан Мечник, Під трьома окупантами, 23).

${ }^{30}$ Осип Назарук, Зі Львова до Вармави, 16. 
ISSN 2078-6077. Наукові зошити історичного факультету Львівського університету. 2018-2019. Випуск 19-20. Proceedings of History Faculty of Lviv University. 2018-2019. Issue 19-20.

вигляд червоноармійців був далекий від хвацького”, всі “були пострижені “під нульку”, мали на собі не шкіряні, а брезентові чоботи, з яких часто “виглядали крізь діру пальці ніг”. Звернула вона також увагу на “недоживленні” солдат, тому “коли відчинилися наші пекарні з цим чудовим пухким ясним хлібом, вони негайно вмішалися в чергу за ним із місцевим населенням. Вони поводилися цілком спокійно та здержливо"з1.

Сприйняття людністю міста радянських вояків було різним: від негативного до відверто радісного ${ }^{32}$. Так, Остап Тарнавський згадує: “одні споглядали вояків у рудих, не надто шиковних одностроях з погордою, інші з недовір'ям, хоч і були такі, які раділи... Між вояками було багато українців, які розмовляли українською мовою, навіть і старшини ${ }^{33}$. Це напевне була запланована показуха, мовляв, братів визволяють рідні брати-українці. Армія увійшла в місто у великих танках, хоч і відкритих, бо й не було потреби їх закривати, ніхто не планував ні одного вистрілу. Пригадую, як на вулиці вийшли львів'яни, головно українці, бо поляки все ще не знали, як їм поступати й яка їхня доля, з танків виходили старшини i ставали до розмови 3 охочими розмовляти" 34 . Наталя Яхненко наголошує, що згодом стало зрозумілим: “такий був наказ згори: поводитися так, щоб не викликати ворожих почувань у місцевого населення. Вони ж бо прийшли “визволяти", а не “завоювати" 35. "Компартія подбала про те, - згадував М. Семчишин, - щоб між “визволителями” Західньої України були й українці..." "з6. Однак прозріння прийшло невдовзі після “золотого вересня”, коли радянська влада “почала показувати своє справжнє обличчя" ${ }^{7}$. М. Семчишин виділив два періоди радянської окупації Західної України: “лагідної пропаганди, прикрашеної українізацією", коли населення раділо таким запровадженим заходам, як українській мові та пісні, написаним українською мовою ${ }^{38}$, залученню до праці в адміністрації українських громадських діячів ${ }^{39}$, та “суворого натиску і

${ }^{31}$ Наталя Яхненко, Від Бюра до Бригідок, 9-10, 13.

${ }^{32}$ Мирослав Семчишин, 3 книги Лева, 63. Радість 3 приводу звільнення Галичини Червоною Армією висловила 26 вересня, зокрема, Народна Рада Галицької землі - організації галицьких московофілів за підписом Ю. Маркова, В. Ваврика, Ю. Юрчаковича та ін., які себе іменували “русские галичане” (Див.: Листування з установами, підприємствами по господарських, адміністративних та інших питаннях, ДАЛО, ф. Р-221, оп. 1, спр. 34 арк. 293).

33 Підтверджує сказане і Іван Прокопів, який занотував: “Бійці і командири говорили поросійськи і по-українськи” (Іван Васильович Прокопів, Спогади, 34).

${ }^{34}$ Остап Тарнавський, Літературний Львів, 1939-1944: спомини, 47-48.

${ }^{35}$ Наталя Яхненко, Від Бюра до Бригідок, 9-10.

${ }^{36}$ Мирослав Семчишин, 3 книги Лева, 63.

${ }^{37}$ Там само, 65.

${ }^{38}$ М. Семчишин згадує про дотеп, який склали львів'яни у зв'язку з українізацією бізнесових вивісок. Перукар-єврей в контексті нових вимог часу зробив вивіску з таким написом: “Тут закладіння для стрижіння волосіння і гоління" (Мирослав Семчишин, 3 книги Лева, 65).

${ }^{39}$ У цьому контексті цікавими є спогади Івана Прокопова, який згадує, що в перші дні радянської окупації, звернувшись з відповідним проханням, отримав роботу старшого бухгалтера в новоствореному облздороввідділі (очільником призначили відомого лікаря Мар'яна Панчишина). 
абсолютного послуху всім розпорядженням влади"40. А наслідки такої стратегії населення вже відчуло “взимку 1939-40 рр., коли розпочалося вивезення у Сибір та Казахстан" "41.

Польське населення міста зайняло вичікувальну позицію. "Було доволі інтелігентних поляків, - згадував Михайло Логаза, - яких “наше” визволення сильно заскочило; вони опинились у ситуації, в якій ніяк не могли себе знайти”

Львів'яни частували воїнів цигарками та задавали їм безліч запитань, водночас розуміючи, що на всі питання буде лише одна позитивна відповідь: в СРСР все чудово ${ }^{43}$. Адольф Слиж згадував агітацію радянських воїнів, які переконували, “що в них всего довільно єсть, але двох тижнів вивезли зі Львова всі товари і віктуали і за хлібом треба було стояти в ряді 2-3 год. перед склепом"44. Дійшло до курйозів, коли на питання одного жартівника чи продається в СРСР косинус, червоноармієць без вагань відповів: “по три рублі фунт"45. Відповіддю, що в Радянському Союзі всього є багато, завершувалися і питання на кшталт: “А шкарлятин у вас много?", “А Амстердамів у вас много? "46.

Зважаючи на декларування атеїстичних поглядів радянських людей, певний подив викликала зовсім інша поведінка прибулих до Львова. Так, часто поранені солдати кликали до себе священика ${ }^{47}$, були випадки хрещення та вінчання, "як тільки "совєтчики" зорієнтувалися, що такі речі не були ще заборонені в новоокупованих землях" $"$.

\footnotetext{
“Окремий кабінет, письмовий стіл, м'яке шкіряне крісло, телефонний апарат, відповідний напис на дверях... Хіба я міг про щось таке подумати за панської Польщі. Ось що дала мені радянська влада, вимагаючи від мене тільки льояльности" (Іван Васильович Прокопів, Спогади, 37). Щоправда, наступний запис, зроблений ймовірно за інших обставин і під впливом арештів, що їх розпочала радянська влада, містить твердження, що визволителі “відразу вели себе, як окупанти” (Там само, 44).

${ }^{40}$ Мирослав Семчишин, 3 книги Лева, 65.

${ }^{41}$ Там само, 66. Однак зазначимо, що попри запевнення радянської влади в миролюбних намірах та прагненні співпрацювати з місцевим населенням, вже в перші дні радянської окупації громадян опанувало відчуття страху за своє життя. Іван Прокопів згадує, як знайома в міському трамваї голосно запитала його, чому він, як інші політичні та громадські діячі, не покинув місто. Він пояснив, що має бажання бути разом з сім'єю, однак занотував, що образився на жінку, бо боявся: "Міг хтось підслухати і подумати, що я великий політичний діяч і могли й невинно арештувати мене". Тому, як зазначив Іван Прокопів, саме через страх він не відвідував свою знайому впродовж 1939-1941 років (Іван Васильович Прокопів, Спогади, 35).

${ }^{42}$ Михайло Логаза, Таке то в нас життя, 234.

${ }^{43}$ Наталя Яхненко, Від Бюра до Бритідок, 10.

${ }^{44}$ Адольф Слиж, Лima, 62.

${ }^{45}$ Наталя Яхненко, Від Бюра до Бригідок, 41.

46 Західня Україна під большевиками, 60-61.

47 "Наші були здивовані, бо вважали всіх “совєтчиків” за безрелігійних істот, а тут був наглядний приклад іскри, що жевріла під накинутим державою безбожництвом” (Наталя Яхненко, Вid Бюра до Бригідок, 37).

${ }^{48}$ Наталя Яхненко, Від Бюра до Бригідок, 38.
} 
ISSN 2078-6077. Наукові зошити історичного факультету Львівського університету. 2018-2019. Випуск 19-20. Proceedings of History Faculty of Lviv University. 2018-2019. Issue 19-20.

Цікавими є спогади про першу хвилю радянських жінок, які прибули до Львова разом з військом. Вони особливо вирізнялися своїм зовнішнім виглядом: одягнені у шинелі, “як і вояки та підперезані ремінними поясами. Але завдяки ширшій будові костей та більшому багатству грудей, ніж жінки Заходу, вони виглядали немов дві снігові кулі, насаджені одна на другу. Цей вигляд “снігової баби” підкреслювався ще тим, що на головах вони мали дуже обтиснені баретки, натягнені майже до брів, що створювало форму третьої малої кулі49. "Добре одягнені жінки військових зачиналися від капітана або майора вгору, при чому ознакою соціяльного статусу було хутро із сибірських білок..." ${ }^{50}$. Червоноармійці погоджувалися 3 наявністю істотних відмінностей від львівських пань, наголошуючи на важкій праці їхніх жінок. Львів'янки мали можливість переконатися у тому, “спостерігаючи, наприклад жінок, заквартированих лейтенантів, як вони зручно розколювали сокирами купи дров або шурували підлоги, або прали на пральних дошках білизну"51. Поступово до міста почали прибувати “канцелярійні робітниці”, які були одягнені “непогано, бо вони мали більше доступу до товарів, а також підробляли собі збоку, писаннями на друкарських машинках вдома" ${ }^{2}$.

Львів'янки, наслідуючи модниць з Варшави та Відня, критично оцінювали зовнішній вигляд прибулих, стверджуючи, що “можна було побачити найбільш дивовижні комбінації одягу”: хутряний короткий жакет 3-під якого виглядала напівпрозора сукня..., а все закінчене повстяними валянками”. Львів'янки, в кімнатах яких розселили радянських жінок, згадували про своє здивування від побаченої “жалюгідної білизни”, а то і їі відсутности. “Зате тутешня білизна мала... величезний попит, особливо нічні вишивані сорочки..., залюбки ношені влітку, як сукні, а також до театру та танців", - згадувала Наталя Яхненко ${ }^{53}$ Відчуття місця та відповідного до нього одягу не було характерне для прибулих: так вчителька могла прийти на заняття “в довгій до землі вечірній сукні, з вирізом на спині по талію”. А чиновниці вищої ранги, мешкаючи в готелі “Жорж”, прийшли на сніданок “в піжамах і були випрошені нашими кельнерами зі стримуваною злорадістю”. Серед головних жіночих уборів були або хустки, або берети, головно червоного кольору. Їх носіння стало приводом до наступного дотепу: на запитання, чому радянські жінки носять червоні берети, відповідь була такою: “Щоб і воші мали свій червоний куток”, пояснюючи, що червоний куток - це місце в кожній установі з портретами “великих вождів”, червоним прапором та офіційною пресою ${ }^{54}$. У цій ситуації, кожен, навіть “бідний пролетар, став почувати

${ }^{49}$ Наталя Яхненко, Від Бюра до Бритідок, 12-13.

${ }^{50}$ Там само, 38 .

${ }^{51}$ Там само, 37

52 Там само, 38

${ }^{53}$ Там само, 39. Подібні враження склалися в Івана Прокопова, який зауважив, що “деякі жінки не розрізняли звичайної сорочки від нічної” та переповів історію про похід “східнячки” до театру в “нічній жіночій сорочці” (Іван Васильович Прокопів, Спогади, 39).

${ }^{54}$ Там само, 40. 
себе вищим культуртрегером у порівнянні з цими “дикунами”, “Азіятами”, як їх прозивали" 55. Мешканців Львова вражав низький рівень освіти та культури у радянських людей, не лише у простих солдатів та урядовців, але й у вищого командного складу ${ }^{56}$.

Однак поступово щоденне життя львів'ян почало змінюватися: жінки в містах перестали носити капелюшки, одягаючи звичайні сірі хустки ${ }^{57}$; мужчини замість капелюхів “почували себе краще в кашкетах". У громадських місцях “скрізь відчувалося грубіянство”. Львів поволі пролетаризувався “і все йшло під стиль вуличного натовпу" 58 . “Для совєтських людей наше зубожіле життя представлялося, як поліпшення їхнього. Для нас же спосіб життя, привезений ними, був деградацією та нуждою. Вони подивляли нашу чемність у публічних місцях, а ми вважали, що у нас росте грубіянство”, - зробила висновок Наталя Яхненко ${ }^{59} .3$ метою самозбереження львів'яни досить швидко перебрали нав'язаний їм стиль одягу та манеру поведінки ${ }^{60}$. Два способи життя зустрічалися у Львові 1939 року: “на сході совєтські люди добивалися “командировок”, себто перенесення до Західньої України, щоб ще скористатися з рештків буржуазних благ та понакупувати, що тільки ще було"б1. А вже через місяць панування у місті радянської влади, сучасники писали: "Назовні це вже був інший Львів: якийсь тупий, сумний, гейби заплаканий...”, а “польські вчорашні великі пані,

\footnotetext{
${ }_{55}^{55}$ Наталя Яхненко, Від Бюра до Бригідок, 41.

${ }^{56}$ Один із львів' ян згадував, що загальноприйнятим словом у воїнів та радянських чиновників, яке мало різне значення, було “давай”. Не менш неприємним моментом у спілкування було звертання до всіх на “ти”, а також “гакання”, що мало значення запиту “що”. Взагалі, як свідчать сучасники, розмова була пересипана грубими жартами й "розперезаним реготом, без уваги на товариство, в якому провадилась”. При цьому наголошувалося, що представники радянської інтелектуальної та мистецької еліти, майже всі представники культури “мали бездоганні форми поведінки" (Західня Україна під большевиками, 75, 78).

${ }^{57}$ Іван Німчук, 595 днів совєтським вязнем, 25.

${ }^{58}$ Мирослав Семчишин, 3 книги Лева, 68.

${ }^{59}$ Наталя Яхненко, Від Бюра до Бригідок, 44.

60 “Кожен 3 нас боявся своїм одягом, товариськими формами або способом життя стягнути на себе закид “буржуазности”, “контрреволюції”, - писав один львів’янин (Західня Україна під большевиками, 82). Подібної точки зору притримувався і Г. Костельник (Див.: Спогади Гавриїла Костельника, Перша зустріч з большевиками, Західня Україна під большевиками, 21).

${ }^{61}$ Наталя Яхненко, Вiд Бюра до Бригідок, 43. Схожими були враження ще одиного львів' янина: “Взагалі наша вбога Галичина видавалась їм країною молоком і медом текучою” (Західня Україна nid большевиками, 81). Українсько-американський славіст-мовознавець Юрій Шевельов (Шнайдер, 1908, Харків - 2002, Нью-Йорк, США), згадуючи свої старання отримати дозвіл на подорож до “Західної” писав у 1940 р.: “Уже майже рік минув від часу окупації, а люди, що відвідали Львів і поверталися звідти, вивозили не бачені в Радянському Союзі речі, частково на себе, частково на продаж. 3 деякими з них не знали, що робити. Оповідали анекдоти про те, як хтось хизувався на вулицях у піжамах, товарі й фасоні мало знаних удома і прийнятих за ознаку високого стилю, шику" (Юрій Шевельов (Юрій Шерех), Я, мені, мене... (і довкруги). Спогади. Видавництво часопису Березіль, 238, http://shron1.chtyvo.org.ua/Sheveliov_Yurii/ Ya_mene_mene_i_dovkruhy_Spohady.pdf).
} 
ISSN 2078-6077. Наукові зошити історичного факультету Львівського університету. 2018-2019. Випуск 19-20. Proceedings of History Faculty of Lviv University. 2018-2019. Issue 19-20.

обмотані “бабушками”, вдавали правдивих пролетарок і ставали в кожний “хвостик” з надією щось дістати чи купити"62.

Зайнявши місто та виконуючи поставлені завдання - організувати постачання міської людности харчами, створити озброєні робітничі загони для встановлення революційного порядку, селянські комітети із представників незаможників і середняків, щоб захопити поміщицькі та монастирські землі - радянські уповноважені почали формувати тимчасові органи влади, оскільки для легітимного оформлення нової політичної системи потрібен був час. Про це ж йшлося у зверненні від 29 вересня 1939 р. командувача Українського фронту Семена Тимошенка “До трудового населення Західної України”"3 . Повноваження на втілення в життя перелічених заходів отримали політичні працівники в армії та НКВС. Частина службовців Польської Республіки втекла на Захід, інша очікувала подальшого розвитку подій. “Вкоротці потворили ріжні уряди і Суди i обсадили своїми урядовцями, а в школах вчили наші вчителі, але управителі шкіл були наслані зі Сходу. До викладів на Університеті покликували і наших професорів і деяких правників"64. У державні установи прибували демобілізовані комісари “у військових шинелях, але без відзнак на цивільних кашкетах" 65.

Українські політичні діячі в перші дні окупації мали неодноразові зустрічі у канцелярії найстаршого галицького політика Костя Левицького ${ }^{66}$. Для презентації інтересів української спільноти перед новою владою вони вирішили створити тимчасовий Допомоговий комітет. Очолив його К. Левицький, секретарем обрали головного редактора часопису “Діло” Івана Німчука ${ }^{67}$. На нарадах також “виринула думка вислати до нової влади делегацію центральних культурноосвітніх та економічно-господарських установ, що мала добитися легалізації діяльности тих установ" 68 . Делегацію у складі 20 осіб очолив Кость Левицький

${ }^{62}$ Мирослав Харкевич, Я вас не забув, 60.

${ }^{63}$ Микола Литвин, Олександр Луцький, Кім Науменко, 1939. Західноукраїнські землі України, $110-111$

${ }^{64}$ Адольф Слиж, Літа, 62; Олександр Луцький, “Інтелігенція Львова (вересень 1939 - червень 1941 рр.)”. Львів: місто - суспільство - культура: Збірник наукових праць. За ред. Мар'яна Мудрого. (Львів: ЛДУ ім. Івана Франка, 1999), 584. Від 1 вересня 1939 р. обов’язки Ректора почав виконувати професор кафедри цивільного права Лоншам де Бер`є (до 18. 10. 1939 р., коли на посаді його змінив призначений днем швидше Народним комісаріятом освіти УРСР Михайло Марченко з Києва). 30 вересня Лоншам де Бер`є оголосив про запланований на 2 жовтня запис до університету (Роман Лоншам де Бер`є, Архів Львівського національного університету імені Івана Франка, ф. Р-119, оп. 1, спр. 102; Роман Лоншам де Бер є, ДАЛО, ф. 26 Університет імені Яна Казимира у Львові, оп. 5, спр. 1096, оп. 6, спр. 839; Adam Redzik, "Szkic o dziejach uniwersytetu Lwowskiego w latach 1939-1946". Львів: місто, суспільство, культура. Том 6. Львів - Краків: діалог міст в історичній ретроспективі. За ред. О. Аркуші й М. Мудрого. Спеціальний випуск Вісника Львівського університету. Серія історична. (Львівський національний університет імені Івана Франка, Львів, 2007), 579).

${ }^{65}$ Наталя Яхненко, Від Бюра до Бригідок, 19.

${ }^{66}$ Осип Назарук, Зі Львова до Варшави, 16.

${ }^{67}$ Мирослав Семчишин, 3 книги Лева, 63; Іван Німчук, 595 днів совєтським вязнем, 17.

${ }^{68}$ Іван Німчук, 595 днів совєтським вязнем, 21, 22. 
(серед делегатів відомі галицькі політики та громадські діячі Роман Перфецький, Степан Баран, Кирило Студинський, Зеновій Пеленський та ін. ${ }^{69}$. Вже 23 вересня вони прибули до першого коменданта Львова генерала Г. Іванова на розмову, яка, за спогадами учасників, “пройшла гарно і гладко”. Зокрема цивільний представник радянської влади (голова Львівського міського ревкому ${ }^{70}$ ) Гаврило Міщенко “українською мовою, розбалакався ширше та обіцяв, як це і $є$ в звичаю большевиків, українському народові всякі блага: і свободу, і землю, і вільний розвиток української культури й господарського життя, і гарячу підтримку радянської влади для всіх добрих українських починів. Запевняв теж, що совєтська влада несе українському народові не тільки визволення, але й добробут, при чому вона не звертатиме уваги на дотеперішню діяльність громадян, вимагатиме тільки від усіх повної льояльности" "71. За оцінкою К. Левицького "Слова були добрі, а діла побачимо"72. І всупереч обіцянкам, уже через кілька днів розпочалися арешти українських діячів ${ }^{73}$, серед яких 30 вересня ув'язнено $\mathrm{i}$ Костя Левицького ${ }^{74}$. "Ніхто з нас не сподівався, - згадував Осип Назарук, - щоб такого старого діяча, який скінчив уже 8-й десяток літ свого життя і від яких 20 літ не займався політичними справами, а працював у кооперації' ...ув'язнили ${ }^{75}$.

Серед іншого на зустрічі з радянським тимчасовим керівництвом йшлося про продовження видання часопису “Діло”. Але, як згадує Остап Тарнавський, “вже в суботу, 23 вересня, у будинку “Просвіти”...3'явились три старшини в одностроях і заявили, що вони редактори ${ }^{76}$.[[...]] Д-р Німчук показав їм редакцію

${ }^{69}$ Осип Назарук, Зі Львова до Варшави, 16-17.

${ }^{70}$ Никита Хрущев, Время. Люди. Власть. (Воспоминания). Книга 1. (Москва: ИИК “Московские Новости”, 1999). http://militera.lib.ru/memo/russian/khruschev1/15.html, доступ отримано 11 червня 2018.

${ }^{71}$ Іван Німчук, 595 днів совєтським вязнем, 22.

${ }^{72}$ Осип Назарук, Зі Львова до Варшави, 18.

73 Іван Німчук згадує про арешт “цілих сотень суддів і прокураторів”, які відгукнулися на заклик радянської влади і прийшли засвідчити своє прагнення працювати у приміщення Галицького Крайового суду при вул. Баторія (нині Князя Романа). Звідти вони вже не вийшли (Іван Німчук, 595 днів совєтським вязнем, 26).

74 За спогадами Костя Левицького, він повірив запевненням радянських керівників, бо “досі не траплялося мені, щоб представники армії й уряду якоїсь держави офіціяльну депутацію населення свідомо оббріхували". Політик називав головною причиною свого арешту саме те, що він “на чолі депутації вітав у Львові радвладу". Такий висновок він зробив із звинувачень слідчого у прагненні обманути радянську владу. На що К. Левицький зауважив: "Найкращим доказом моєї доброї волі $є$ те, що коли тов. Мищенко заявив депутації, що громадянство мусить бути лояльне до радянської влади та притримуватися радянської плятформи, тоді ми рішили УНДО розв'язати і закликали всіх членів ставитись льояльно до Совєтів" (Сеньйор українських політиків большевицьким в'язнем. Спогади К. Левицького, Західня Украӥна під большевиками, 381-384).

${ }_{75}^{7}$ Осип Назарук, Зі Львова до Варшави, 19.

${ }^{76}$ Про ці події згадує також Іван Німчук (Див.: Іван Німчук, 595 днів совєтським вязнем, 26-29), голова "Просвіти” Іван Брик (Див.: Спогади Івана Брика. Замість "Просвіти" - Звізда Совєтів", Західня Україна під большевиками, 252-253), 
ISSN 2078-6077. Наукові зошити історичного факультету Львівського університету. 2018-2019. Випуск 19-20. Proceedings of History Faculty of Lviv University. 2018-2019. Issue 19-20.

і друкарню з вірою, що все ще можна буде затримати “Діло” як незалежний часопис. Та в неділю прибуло до редакції вже яких сорок редакторів на чолі 3 редактором "Комуніста" з Києва Андрієм Терентійовичем Чеканюком, і вони стали господарями будинку"77.

Власне Іван Німчук згадує про нараду українських журналістів (приблизно 80 осіб), що скликав 25 вересня А. Чеканюк і котра відбувалася у будинку "Просвіти" (пл. Ринок, 10). На зустрічі був присутній письменник Олександр Корнійчук ${ }^{78}$, “який грав роль дуже ввічливого і приязного в розмовах співбесідника"79. Однак, з вуст радянського чиновника А. Чеканюка звучали звинувачення в “угодовській політиці" щодо Польщі й жодні пояснення суті політики нормалізації УНДО до уваги не бралися. У той же день з друкарні “Діла" вийшов перший номер газети "Вільна Україна"в0.

Порядок у місті мала забезпечувати новостворена міліція, хоча, як згадують очевидці, і вона була розгублена, “бо не знала ні своїх прав, ні обов'язків, ні людей”"1. Перша маніфестація, організована КПЗУ (близько 300 осіб), пройшла в неділю 24 вересня ${ }^{82}$. На всіх львівських кам'яницях за одну ніч появилися червоні прапори, що, як згадує Іван Німчук, було легко зробити, “бо сторожі домів повіддирали з дотеперішніх польських прапорів їх білу частину, і червоні прапори були готові" ${ }^{83}$.

Отже, судячи зі спогадів очевидців, підтверджених студіями науковців, у вересневі дні загалом у Галичині та, зокрема, у Львові, панувала ейфорія, пов'язана з визволенням краю від польського панування. Хоча можна погодитися 3 твердженням українських дослідників, що “зовнішній ентузіязм багатьох мешканців не можна ототожнювати з радянофільством”, а швидше розцінювати як “спонтанну реакцію на падіння" польської влади ${ }^{84}$. Тому не дивно, що Червону армію подекуди зустрічали квітами та хлібом-сіллю, а свою лояльність до нової влади засвідчували відомі громадські діячі Львова (композитори Станіслав Людкевич і Володимир Барвінський, лікар Мар'ян Панчишин ${ }^{85}$ та інші).

У різних спогадах містяться однакові сюжети, повторення яких можуть свідчити про те, наскільки глибоко саме вони врізалися в пам'ять. Йдеться, насамперед, про дві прикмети радянських людей, які кидалися у вічі: бідність, що було показником економічної ситуації в УРСР та СРСР загалом, та відсутність елементарних норм культури поведінки, що свідчило про соціяльно-побутовий

\footnotetext{
${ }^{77}$ Остап Тарнавський, Літературний Львів, 1939-1944: спомини, 23-24.

${ }_{78}$ Вільна Україна. Орган політичного управління Українського Фронту. Львів, 26.09.1939. № 2,2 .

${ }^{79}$ Остап Тарнавський, Літературний Львів: спомини, 23.

${ }^{80}$ Вільна Україна. 25.09.1939. № 1.

${ }^{81}$ Мирослав Харкевич, Я вас не забув, 60.

${ }^{82}$ Вільна Україна. Львів, 26.09.1939. № 2, 3.

${ }^{83}$ Іван Німчук, 595 днів совєтським вязнем, 21.

${ }^{84}$ Микола Литвин, Олександр Луцький, Кім Науменко, 1939. Західноукраӥнські землі Украӥни, 98.

${ }^{85}$ Вільна Україна. 28. 09. 1939. № 4, 2; 29. 09. 1939. № .5, 2.
} 
уклад життя радянської людини. І якщо бідність ще могла викликати співчуття, то невихованість вражала і викликала відразу. Хоча через інстинкт самозбереження львів'яни досить швидко адаптувалися та сприйняли нав'язану манеру поведінки, принаймні в зовнішніх вимірах.

\title{
NINE DAYS OF “GOLDEN SEPTEMBER” 1939 IN THE MEMOIRS OF UKRAINIAN EMIGRANTS FROM LVIV
}

\author{
Zoya BARAN \\ Ivan Franko National University of Lviv \\ Department of Modern and Contemporary History of Foreign Countries \\ Universytetska str., 1, 79000, Lviv, Ukraine \\ e-mail: zoja_baran@ukr.net
}

The article is based on published in the postwar period, mainly in the United States, eleven memo $^{3}$ rs of Ukrainian emigrants from Lviv The author describes the first nine days of the Soviet occupation of Lviv in 1939. Memoirists are people of various occupations (writers, lawyers, doctors) and age (as of 1939 they were from 14 to 56 years old). Their memories, were collected and published directly during and after these events, and to reproduced the first impressions of Ukrainian burghers about the Red Army soldiers and soviet officials (men and women) who arrived in the city. The most striking thing about this is the horrific appearance of the soldiers, which showed the signs of hunger and, to a certain extent, the economic crisis in the state they were representing. Similar arguments can be applied to military equipment. These impressions left the inhabitants puzzled because of the possibility of comparisons with the state of the previous Polish and German troops. The next characteristic feature of the Red Army soldiers and Soviet officials is the fear: they were forced to praise the Soviet reality, to always be fully equipped, to speak and act constantly looking around. Low level of education, inability to express themselves and behave according to the situation - the features, that were seen by Lviv citizens of Soviet officials. Women of Lviv who followed the fashionistas from Warsaw and Vienna were most surprised at the sloppiness, the lack of taste and style in Soviet women who did not have a sense of dress appropriate to the place. Thus, it is possible to distinguish two signs of the Soviet people: the poverty, which demonstrated to the real economic situation in the Ukrainian SSR and the USSR, and the lack of elementary norms of the culture of behavior, which reflected the social and everyday way of life of the Soviet man in general. Through the instinct of self-preservation, the Lviv adapted rather quickly and accepted the imposed manner of behavior, at least in its external dimensions. Soviet propaganda of unconditional atheism was not accepted among the people of Lviv. Evidence of this was the numerous cases of weddings and baptisms. Regarding public attitudes, the Ukrainian population of the city was in euphoria from liberation from the Polish rule On the other hand, the manner of behavior and actions of the newly-established authorities, took it with distrust, and sometimes with fear. However, many representatives of the Ukrainian intelligentsia began to fulfill their duties, believing in the declaration of Soviet power. A proof of loyalty to the new government should be the decision of the leadership of the legal Ukrainian political parties to cease activities. However, the closure of the periodicals and the first arrests of public and political figures (including the oldest representative of Ukrainian politics, 80-year-old Kost Levytsky) put an end to the hopes for Ukrainianization and democratization of life in the city.

Key words: Lviv, "Golden September 1939”, Soviet occupation, Red Army. 
ISSN 2078-6077. Наукові зошити історичного факультету Львівського університету. 2018-2019. Випуск 19-20. Proceedings of History Faculty of Lviv University. 2018-2019. Issue 19-20.

\section{REFERENCES}

Bonusiak, Włodzimierz. "Mieszkañcy Lwowa podczas II wojny œwiatowej”, Lviv: misto suspilstvo-kultura: Zbirnyk naukovykh prats. T.6: Lviv-Krakiv: dialoh mist v is torychnii retrospektyvi. Za red. Oleny Arkushi ${ }^{3}$ Mariana Mudroho. Visnyk Lvivskoho universytetu. Seriia istorychna. Spetsialnyi vypusk, (Lviv: Lvivskyi natsionalnyi universytet imeni Ivana Franka, 2007). 535-545. (in Polish)

Danyliuk, Arkhyp. Shliakhamy Ukrainy. Etnohrafichnyi narys. (Lviv: Vydavnytstvo "Svit", 2003), 256 s. (in Ukrainian)

Helei, Stepan. Dmytro Velykanovych", Naukove tovarystvo Shevchenka. Entsyklopediia. T. 2.: Bibl- Ves. Red. tomu: O. Kupchynskyi (Vidp. red.), O. Savula, N. Fedorchak. Naukove tovarystvo im. Shevchenka; Instytut entsyklopedychnykh doslidzhen NAN Ukrainy. Kyiv, Lviv, Ternopil, 2014, 543-544.

Kharkevych, Myroslav. Ya vas ne zabuv. Spohady 1935-1935. (Niu-York, Chikaho: Nakladom ukrainsko-amerykanskoi fundatsii Volia, 1997). 288 s. (in Ukrainian)

Kharkevych, Myroslav. http://www.legacy.com/memorial-sites/veterans/profilesearch.aspx?\&firstname $=$ Myroslaw $\% 20$ \&lastname $=\% 20$ Charkewycz $\% 20 \&$ daterange $=9999$, dostup otrymano 9 chervnia 2018. (in English)

Khrushchev, Nykyta. Vremia. Liudy. Vlast. (Vospomynanyia). Knyha 1. (Moskva: "Moskovskye Novosty", 1999). http://militera.lib.ru/memo/russian/khruschev1/15. html, dostup otrymano 11 chervnia 2018. (in Russian)

Lohaza Mykhailo. Take to v nas zhyttia. Spohady-promovy-esei-komentari. Vybrane pro okhoronu zdorovia. (Syrakiuzy; Niu York, 1985). 353 s. (in Ukrainian)

Longchamps de Berier, Roman. Arkhiv Lvivskoho natsionalnoho universytetu imeni Ivana Franka, f. R-119, op. 1, spr. 102. (in Ukrainian)

Longchamps de Berier, Roman. Derzhavnyi arkhiv Lvivskoi oblasti, f. 26 Universytet imeni Yana Kazymyra u Lvovi, op. 5, spr. 1096;op. 6, spr. 839. (in Ukrainian)

Lutskyi, Oleksandr. "Intelihentsiia Lvova (veresen 1939 - cherven 1941 rr.)". Lviv: misto suspilstvo - kultura: Zbirnyk naukovykh prats. Za red. Mariana Mudroho. (Lviv: LDU im. Ivana Franka, 1999), 574-591. (in Ukrainian)

Lystuvannia z ustanovamy, pidpryiemstvamy po hospodarskykh, administratyvnykh ta inshykh pytanniakh, Derzhavnyi arkhiv Lvivskoi oblasti, f. R-221, op. 1, spr. 34 ark. 293). (in Ukrainian)

Lytvyn, Mykola, Lutskyi, Oleksandr, Naumenko, Kim. 1939. Zakhidnoukrainski zemli Ukrainy. (Lviv: Instytut ukrainoznavstva im. Krypiakevycha NAN Ukrainy, 1999), 152 s. (in Ukrainian)

Lytwyn, Mykola. "Wojskowa kampania niemiecko-sowiecka roku 1939 w Galicji” in Od wojny do wolnoæci. Wybuch I konsekwencje II wojny owiatowej 1939-1989, redakcja naukowa Marek Andrzejewski, Grzegorz Berendt, Tomasz Chinciński, Andrzej Trzeciak. GdańskWarszawa: Wydawnictwo Naukowe Scholar Spólka, 2010, 40-58. (in Polish)

Mashynopysni kopii materialiv z hazet z povidomlenniam pro zvilnennia Lvova i Ukrainski Narodni Zbory, Derzhavnyi arkhiv Lvivskoi oblasti, f. R-300, op. 1, spr. 44. (in Ukrainian)

Mechnyk, Stepan. Pid troma okupantamy: spohady ukrainskoho revoliutsionera-pidpilnyka. Pamiati polehlykh Heroiv za voliu Ukrainy. (London: Nakladom ukrainskoi vydavnychoi spilky, 1958). 106 s. (in Ukrainian)

Naumenko, Kim. "Misto naperedodni i na pochatku svitovoi viiny" v knyzi Istoriia Lvova. U trokh tomakh. Tom 3. Lystopad 1918 - poch. $\tilde{O}^{2}$ st. Redkolehiia Yaroslav Isaievych, Mykola Lytvyn, Feodosii Steblii, (Lviv: Tsentr Yevropy, 2007). 163-169. (in Ukrainian)

Nazaruk, Osyp. Zi Lvova do Varshavy. Utecha pered sovitamy v pamiatnykh dniakh 2-13 
zhovtnia 1939 roku. (Lviv: Naukove tovarystvo im. Shevchenka, 1995). 96 s. (in Ukrainian)

Nekroloh. Michael Jaworskyj, http://www.pagosasun.com/michael-jaworskyj/, dostup otrymano 9 chervnia 2018. (in English)

Nimchuk Ivan. 595 dniv sovietskym viaznem. (Toronto, 1950). 238 s. (in Ukrainian)

Petelytskyi Stepan, Do Osventsimu za Ukrainu. Per. z anh. O. Terekha. (Kyiv: Suspilna Sluzhba Ukrainy, 2000). 120 s. (in Ukrainian)

Prokopiv, Ivan Vasylovych. Spohady. Lvivska natsionalna naukova biblioteka Ukrainy imeni V. Stefanyka. Viddil rukopysiv, f. Prok. 75, p. 7. 193 s. (in Ukrainian)

Redzik, Adam. "Szkic o dziejach uniwersytetu Lwowskiego w latach 1939-1946". Lviv: misto, suspilstvo, kultura. Tom 6. Lviv-Krakiv: dialoh mist v istorychnii retrospektyvi. Za red. O. Arkushi i M. Mudroho. Spetsialnyi vypusk Visnyka Lvivskoho universytetu. Seriia istorychna. (Lviv: Lvivskyi natsionalnyi universytet imeni Ivana Franka, 2007). 577-592. (in Polish)

Semchyshyn, Myroslav. Z knyhy Leva. Ukrainskyi Lviv dvadtsiatykh-sorokovykh rokiv. Spomyny. (Lviv: Naukove tovarystvo im. Shevchenka, 1998), 146 s. (in Ukrainian)

Shevelov, Yurii (Iurii Sherekh). Ya, meni, mene... (i dovkruhy). Spohady. Vydavnytstvo chasopysu Berezil, 409 s. http://shron1.chtyvo.org.ua/Sheveliov_Yurii/ Ya_mene_mene_i_dovkruhy_Spohady.pdf(in Ukrainian)

Slyzh, Adolf. Lita. Spohady. (Lviv: Manuskrypt, 2014), 156 s. (in Ukrainian)

Tarnavskyi, Ostap. Literaturnyi Lviv, 1939-1944: spomyny, (Lviv: Piramida, 1995), 136 s. (in Ukrainian)

Velykanovych, Dmytro. "Shkilna polityka suproty Ukrainy (z promovy posla Velykanovycha, vyholoshena na plenarnomu zasidanni soimu 21 liutoho 1936 r. pry biudzheti ministerstva osvity)", Ridna shkola (Lviv), 1936, ch. 7-8, s. 108-109. (in Ukrainian)

Velykanovych, Dmytro. "Ukrainske vchytelstvo v Polshchi u svitli statystyky", Ridna shkola (Lviv), 1936, ch.19, s. 193-95. (in Ukrainian)

Velykanovych, Dmytro. "Ukrainske vchytelstvo v Polshchi u svitli statystyky", Svoboda. Ukrainskyi shchodennyk (Dzherzi Syti), 22. 10. 1938, rik XLVI, ch. 246, s. 2-3. (in Ukrainian)

Vilna Ukraina. Orhan politychnoho upravlinnia Ukrainskoho Frontu. Lviv, 25. 09. 1939. № 1; 26. 09. 1939. № 2; 28. 09. 1939. № 4; 29. 09. 1939. № 5. (in Ukrainian)

Yakhnenko, Natalia. Vid Biura do Bryhidok. Trokhy spohadiv z 1939-1941 rokiv. (Lviv; Beralia; Miunkhen, 1986), 263 s. (in Ukrainian)

Yavorskyi, Mykhailo. Potsilunok Leva. Roman. (Lviv: Literaturna ahentsiia Piramida, 2006), 264 s. (in Ukrainian)

Zakhidnia Ukraina pid bolshevykamy. Uporiad. Milena Rudnytska. (Niu-York: Naukove tovarystvo im. Shevchenka v USA, 1958). 494 s. (in Ukrainian) 
